\title{
Study of Erosion Processes in the Tinto Salt-Marshes with Remote Sensing Images
}

\author{
Emilio Ramírez-Juidías \\ School of Agricultural Engineering, Universidad de Sevilla, SPAIN; \\ erjuidias@us.es
}

\begin{abstract}
Both climatic factors and the sea wave energy are two important factors to study the tidal wetlands. One of the most important wetlands in the Southwest of the Iberian Peninsula is the Tinto salt-marshes, the third largest wetland in Andalusia after Doñana and Odiel salt-marshes. From 1956 to 2010 the land use changes (LUC) have given rise to a great landscape transformation that along with the effects of recent climate change, have caused a strong impact on the environment. With the development of image processing techniques and use of unmanned aerial vehicles (UAVs) is possible to obtain patterns of erosion sufficiently precisely. In this paper, a new methodology patented by the author is presented and used to obtain the total volume of eroded soil in the Tinto salt-marshes. In the same way, the different causes that give rise to this phenomenon as well as the influence of intertidal processes are discussed. The results shown how the erosion processes are an immediate consequence of the low kinetic energy in the Tinto river and hence of the progressive increase of the negative rate of eroded soil.
\end{abstract}

Keywords: Unmanned aerial vehicle, Eroded soil, Wave energy, Wetlands.

\section{Introduction}

According to [1], concern over sediment and erosion has shifted recently from on-site effects on productivity and engineering stability to downstream influences on in-stream and estuarine ecosystems. Human activity has caused hitherto the acceleration of both sediment and erosion processes as well as other also negative, so that wetlands have lost much of its original area $[2,3]$.

Although ecosystem processes with their implications for the future progress of land degradation have been studied at numerous field sites around the world, it is difficult to extrapolate findings from field studies at patch scale in other areas [4, 5]. Though satellite platforms may contribute to the solution of this problem, the use of UAVs presents an 
important advantage because it allows us to represent all the topographical features of the saltmarshes, which are often insufficiently reflected in conventional contour lines mapping [6, 7], thereby supplying the spatial information needed for marshes-scale analyses of the relationships between climate change and soil erosion.

In Tinto salt-marshes, the residence times of sediment in their river system are long with much intermediate storage of eroded material, as is common to most large river systems around the world, and as occurs in Australia [1]. By the other hand, increased storage of sediment can results in substantial changes to Tinto river's physical form and their ecological health. This last aspect is very important as a consequence of the importance of this river to the study of life in extreme conditions. In addition, there is no doubt that within Tinto river system there is a great diversity of impacts of the changed sediment regime.

A further consequence of long residence times in rivers, and according to [1], is that the major historical changes will continue to influence river behavior for many decades to come. Likewise, this makes it crucial for us to predict the trajectory of response to historical change, being the temporal scale of analysis of decades or longer due to the great relevance of the net response of sediment to the distribution of floods over many years.

Hitherto, most remote sensing studies have attempted to approach loss soil and their erosion processes solely through mapping changes in vegetation cover and abundance, or LUC in general sense, and even with different methods capable of derive state variables based on the reflectance characteristics of soils [4] and/or the characteristics of the vegetable canopy. However, although the use of UAVs can be considered recent, the percentage of published papers is much greater perhaps it can be due to the huge potential of UAVs in the different techniques used in remote sensing.

The quantification of erosion processes through UAVs, with the help of ground work, can provide new required insights to predict the total volume of eroded soil not only in any wetland but also elsewhere of the world. However, when the area is compound for a complex network of catchments and/or aquifers, it is necessary to use high-resolution orthophotography. A feasible solution is the use of new images processing techniques, which are nowadays accepted by the scientific community.

\section{Materials and Methods}

\subsection{Study Area}

The Tinto salt-marshes (Figure 1), with a total area of $32,867,946.31 \mathrm{~m}^{2}$, are located in the province of Huelva (Southwest of the Iberian Peninsula), associated to Tinto river mouth. These salt-marshes are located to $3.5 \mathrm{~km}$ of Odiel salt-marshes. 


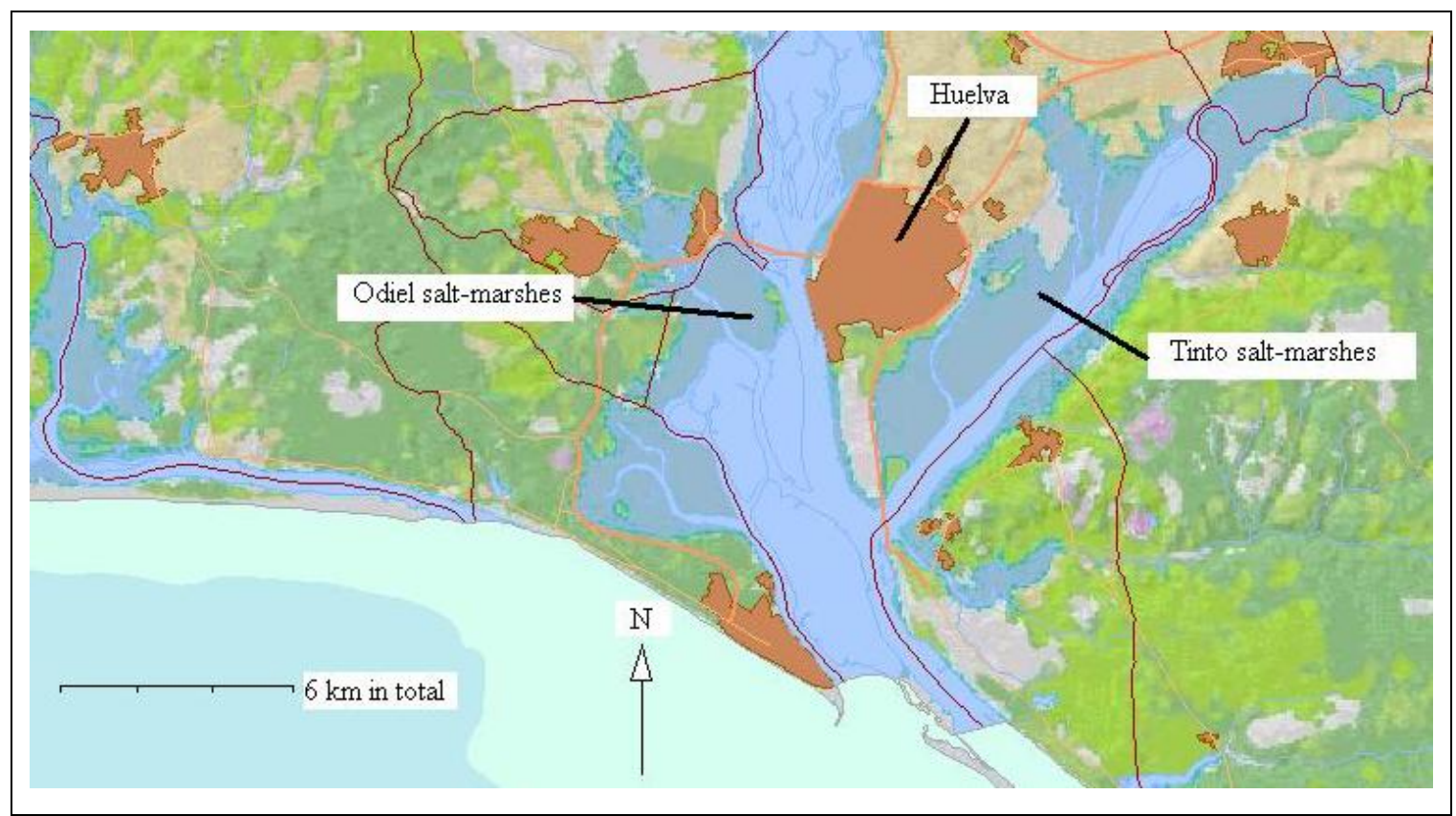

Figure 1: Location of Study Area

According to [7], the area is integrated in a complex system of estuaries of recent sedimentation influenced, in their genesis, by level changes of Earth's crust [8]. All set is surrounded by Tertiary formations of yellow silt and Miocene marls, Pliocene sands and marls, and remains of a Pleistocene erosive glacis. In the Tinto salt-marshes are given simultaneously both sedimentation and erosion processes that vary in space and time, creating a lot of temporary or permanent physiographic characteristics giving rise to a considerable variety of habitats. The tidal movement is the main determining factor in shaping of these ecosystems.

The area consists of a tidal marsh area well preserved and another area, Dehesa de Alquería, where both forest and dry-land crops are predominant. The part of dry land located to the North consist of clayey soils on which run a small stream whose mouth give rise to the formation of two small freshwater lagoons where every year an abundance of ducks, geese, and swans overwinter, and is used as breeding area by wading birds, small-to medium-sized ground-living birds (Rallidae or rails), ducks, geese, and swans.

In the environment there is high anthropic influence. Tinto salt-marshes are close to the Tartessos' Industrial Park, where raw sewage and solid waste pour into the area from the National Cellulose Company. In the West is located the solid waste landfill of Huelva, where abounds discharges of rubble due to the existence of the brownfield site. The vulnerability of the area depending on the risk of threat to natural habitats is shown in Figure 2. 


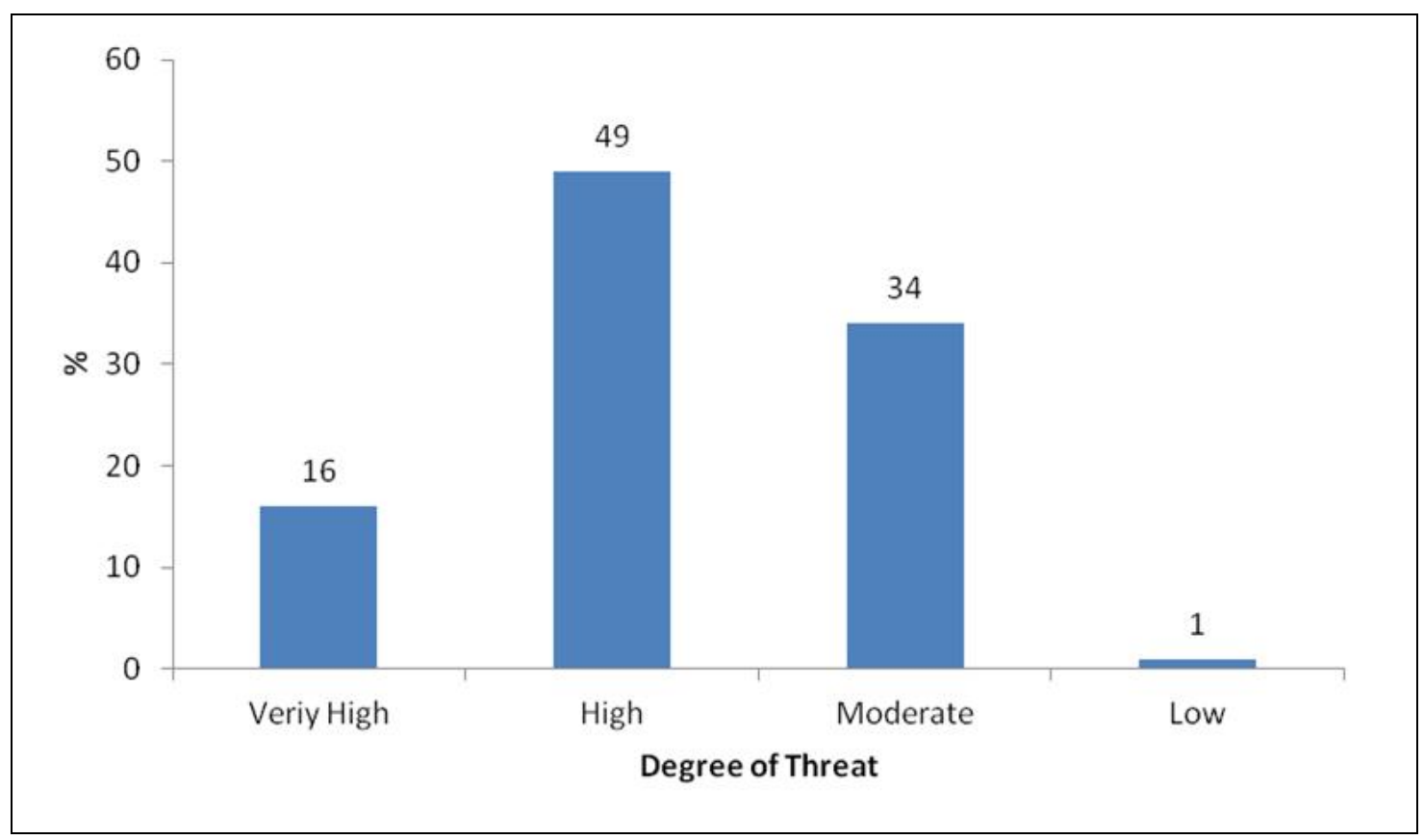

Figure 2: Surface's Distribution by Degree of Threat

In another vein, the climate in the study area can be defined as mediterranean maritime, with and insolation grade exceeding 3,000 h/year. In the winter season, notable for a short period of low temperatures, most of the rains occur. On the other hand, the summers are dry and long though smoothed out by the proximity of the ocean, not exceeding, usually, the absolute maximum temperature of $44^{\circ} \mathrm{C}$. The average annual rainfall is $483.922 \mathrm{~mm}$, being concentrated in the months of December and January, presenting, likewise, a dry season with deficient water balance between the months from May to September [7].

\subsection{Data and Methodology}

For the investigation was necessary to establish a total of 23 control points distributed within the study area (Figure 3), all of them identified by georeferenced photogrammetric images for the initial period 1973 to 2010 obtained from Iberpix (National Geographic Institute of Spain). Likewise, during the month of September 2013, images were acquired of the study area via an UAV, which were georeferenced in the European Terrestrial Reference System 1989 (ETRS-89). The UAV was equipped with a miniature radar system capable of collect and record the different points of study area. 


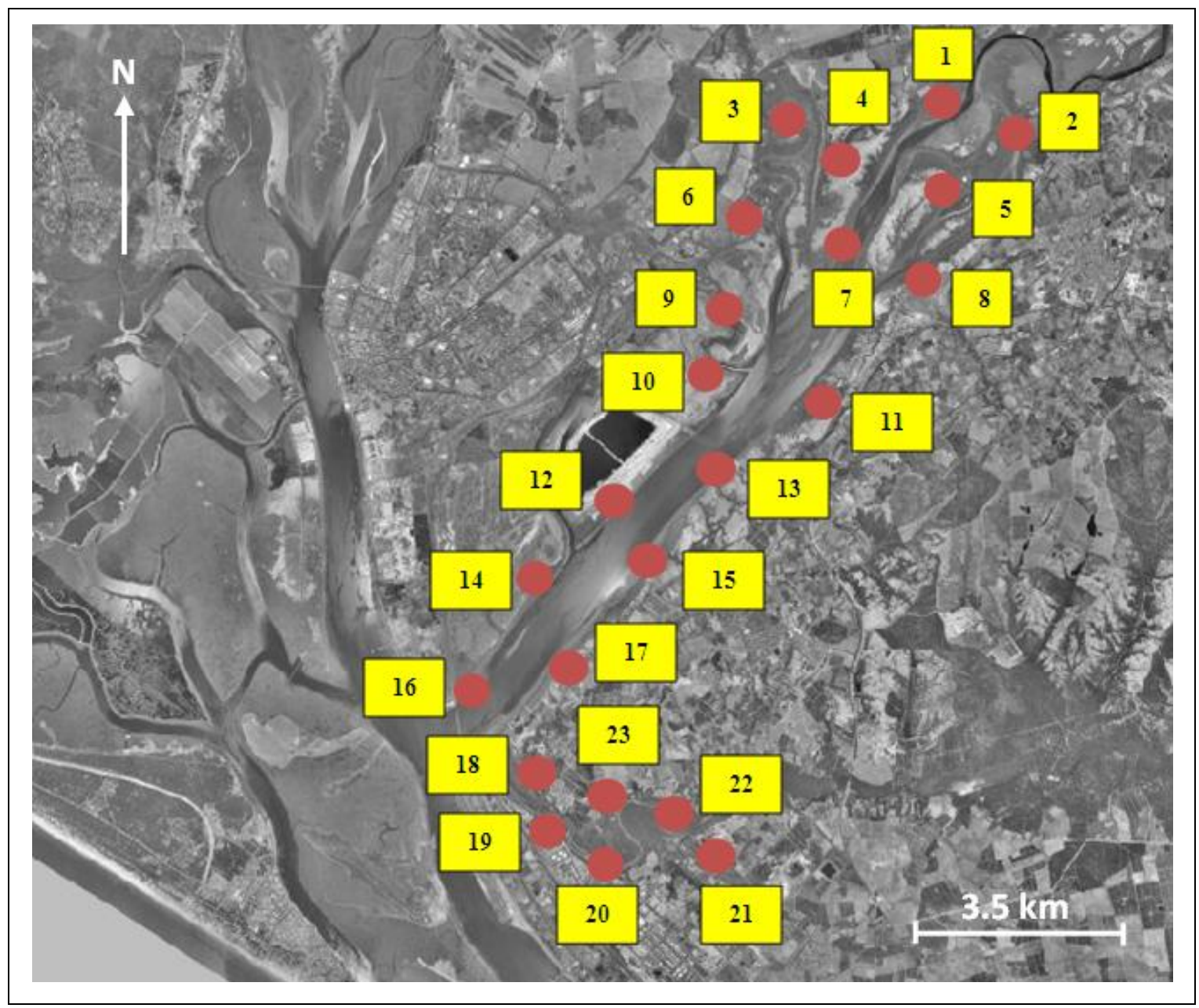

Figure 3: Distribution of Control Points in the Study Area

To obtain a good analysis of the study area it was necessary establishing two periods of time into the initial established period (1973-1985 and 1985-2010), which was compared with the data collected in situ via UAV in September 2013 to be able to obtain the total volume of erosioned soil in Tinto salt-marshes.

For each period all images, including the UAV images, were orthorectified with a 25 (first period 1973-1985), 10 (second period 1985-2010) and 5 (UAV data) $m$ resolution digital elevation model (DEM) belonging to Andalusian Government (second period) and the National Geographic Institute of Spain (all other periods). These DEM's provide suitable resolution to obtain the different levels of Tinto salt-marshes with the help of the control points selected within the study area [9] and iterative processes [10]. Also through iterative processes were obtained, in each pixel of both photogrammetric and UAV images, the average water depth of Tinto salt-marshes in each period, which was necessary to obtain the erosioned soil in these salt-marshes.

According to [7], an additional deep literature review was completed aimed to determine the possible existence of a temporal record of precipitation in the Tinto salt-marshes broad enough to obtain results, discussions and conclusions coherent with the present study. In this 
regard the precipitation data was analyzed from meteorological stations located in Lepe, Moguer, Almonte and Doñana salt-marshes in order to predict the precipitation data in Tinto salt-marshes from 1900 to 2010 (Figure 4) starting from the correlation among the different meteorological stations $(r=0.92)$.

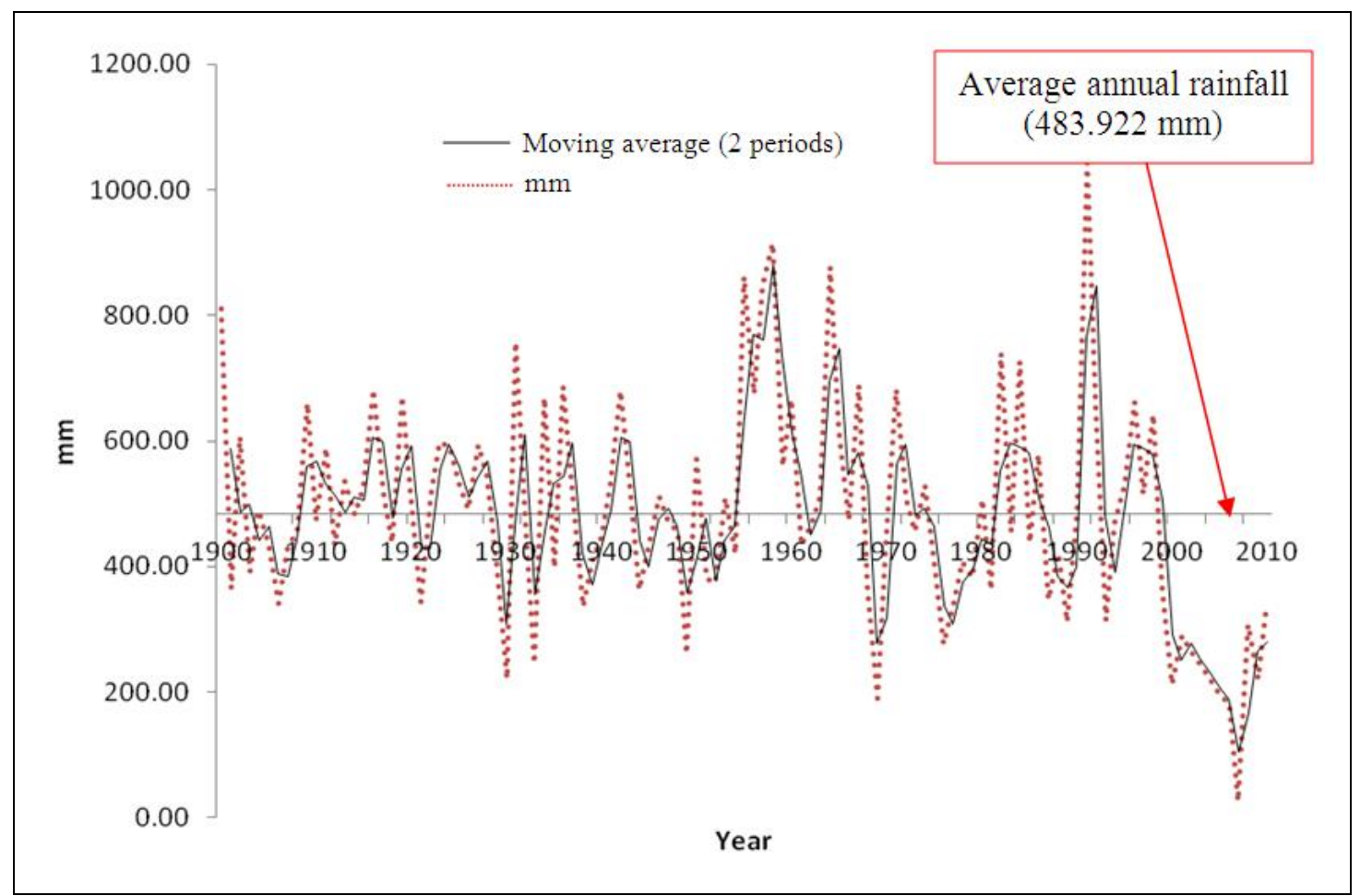

Figure 4: Estimated Rainfalls in the Study Area

\section{Results and Discussion}

\subsection{Land Use Changes}

Regarding altered or constructed areas, and after conducting a detailed study of web master service (WMS) layers obtained from REDIAM (REd De Información AMbiental de Andalucía "Environmental Information Network of Andalusia") for the period from 1956 to 2007 , can be appreciated (Figure 5) a significant increase of these areas $\left(6,544 \cdot 10^{4} \mathrm{~m}^{2}\right.$ in $1960 \mathrm{~s}$, $16,237 \cdot 10^{4} \mathrm{~m}^{2}$ in $1990 \mathrm{~s}$ and $22,323 \cdot 10^{4} \mathrm{~m}^{2}$ in 2000s) due to the expansion of the urban fabric and the construction of new housing estates, mainly on the coast [11], where the built-up area has increased six-fold due to tourism development, intensive agriculture and rising industrialized areas. 


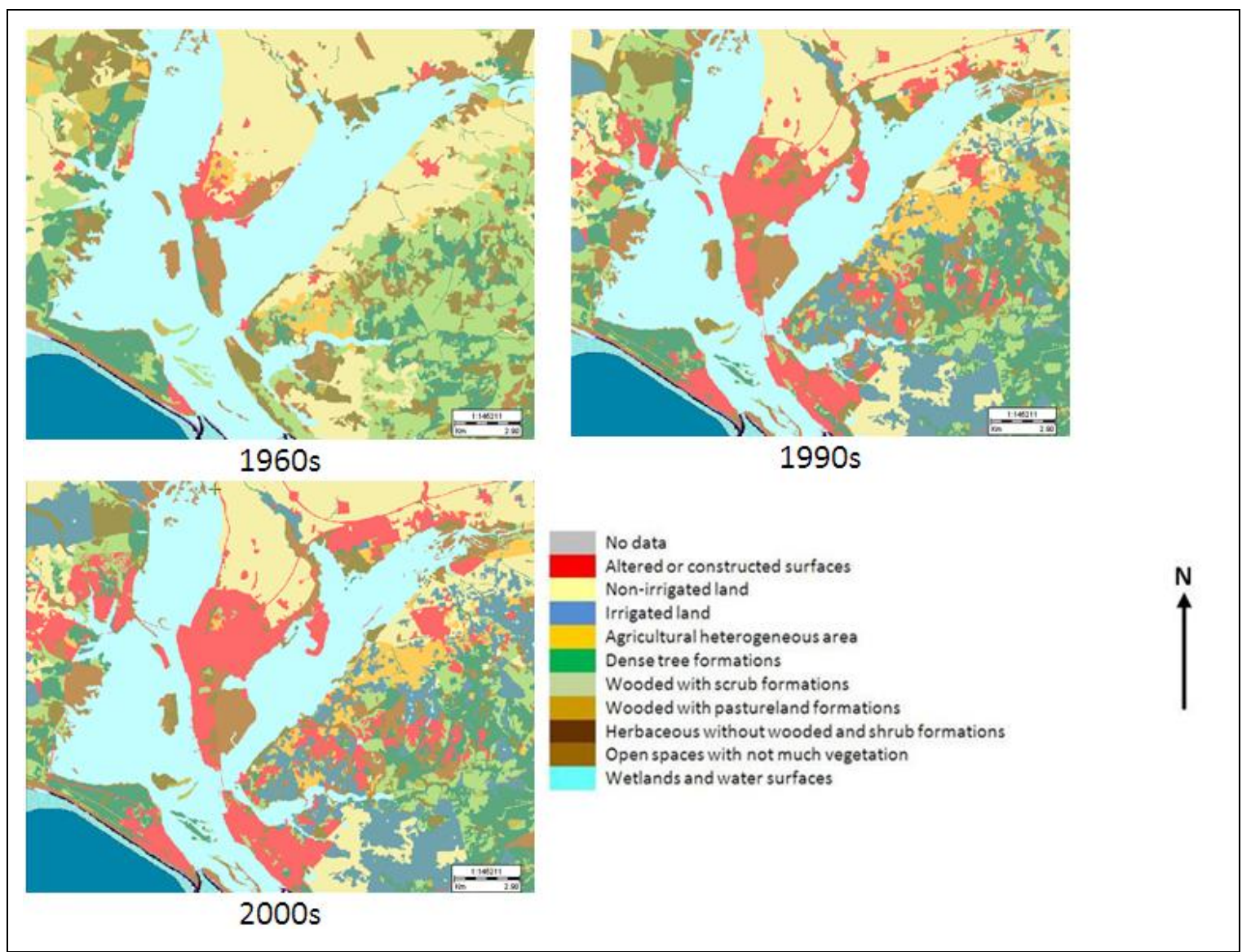

Figure 5: Land Use Changes in the Study area for 1960s, 1990s and 2000s

In respect to agricultural area there was a decline of $3 \cdot 10^{7} \mathrm{~m}^{2}$ between 1956 and 2007 . The evolution followed by different rain fed lands has been uneven, while the arable crops area has remained relatively stable, the extent of other crops has experienced sharp decreases, so that the total area has lost $23 \%$ of its original extent. Noted is the drastic reduction of crops' mosaics and natural vegetation, which record the loss of $60 \%$ of the area occupied in 1956 [11].

In contrast to the abandonment or conversion to forest uses rain fed crops, the area dedicated to irrigation has increased to over $43 \cdot 10^{7} \mathrm{~m}^{2}$ in 2007 , mainly emphasizing greenhouse crops and citrus located in the municipalities of Almonte, Lepe, Lucena del Puerto, Gibraleón, Cartaya, Palos de la Frontera and Moguer [11].

In another vein, wetlands and water surfaces had a slight increase of $2,564 \cdot 10^{4} \mathrm{~m}^{2}$ between 1956 and 2007, registering the major changes in littoral wetlands, being the total area $9 \%$ lower than its original extent $\left(33 \cdot 10^{7} \mathrm{~m}^{2}\right.$ in 1956).

The loss of wetlands and littoral water areas is related to the LUC produced in both Odiel and Tinto salt-marshes. According to [12] the biggest changes in tidal marshes have been for their suitability as industrial salinas and aquatic park crops in Odiel salt-marshes, the arrow of El Rompido and the mouth of the Guadiana river' $\left(44 \cdot 10^{5} \mathrm{~m}^{2}\right.$ in 1956 and $17 \cdot 10^{6} \mathrm{~m}^{2}$ in 2007). 
The LUC of forestry and natural areas have particular importance given the size of these spaces in the province of Huelva $\left(778,921 \cdot 10^{4} \mathrm{~m}^{2}\right.$ in $1960 \mathrm{~s}, 784,322 \cdot 10^{4} \mathrm{~m}^{2}$ in $1990 \mathrm{~s}$ and $763,533 \cdot 10^{4} \mathrm{~m}^{2}$ in 2000 s due to their conversion in agricultural areas). According to [12], the reforestations (mostly eucalyptus) carried out explain the evolution followed by wooded forest area in the study area, as well as the loss of a third of the $306,126 \cdot 10^{4} \mathrm{~m}^{2}$ occupied in 1956 by treeless scrub formations.

Finally, it is important to mention the two processes that accelerate the conversion of forest stands in scrub areas or pastureland and therefore the change of typology within the LUC of forestry and natural areas, i.e., forest fires (nearly 7,889.10 $\mathrm{m}^{2}$ between 1999 and 2007) and the oak decline of Quercus (this disease causes the death of both holms and cork oaks and reduces the economic profitability of the dehesa) [11].

\subsection{Prediction of the Volumetric Change Processes}

After analyzing the meteorological data it was determined [5] that a correlation between precipitation data from Doñana and Tinto were sufficiently significant $(\leq 0.001)$ to obtain an equation to predict the data presented in Figure 6.

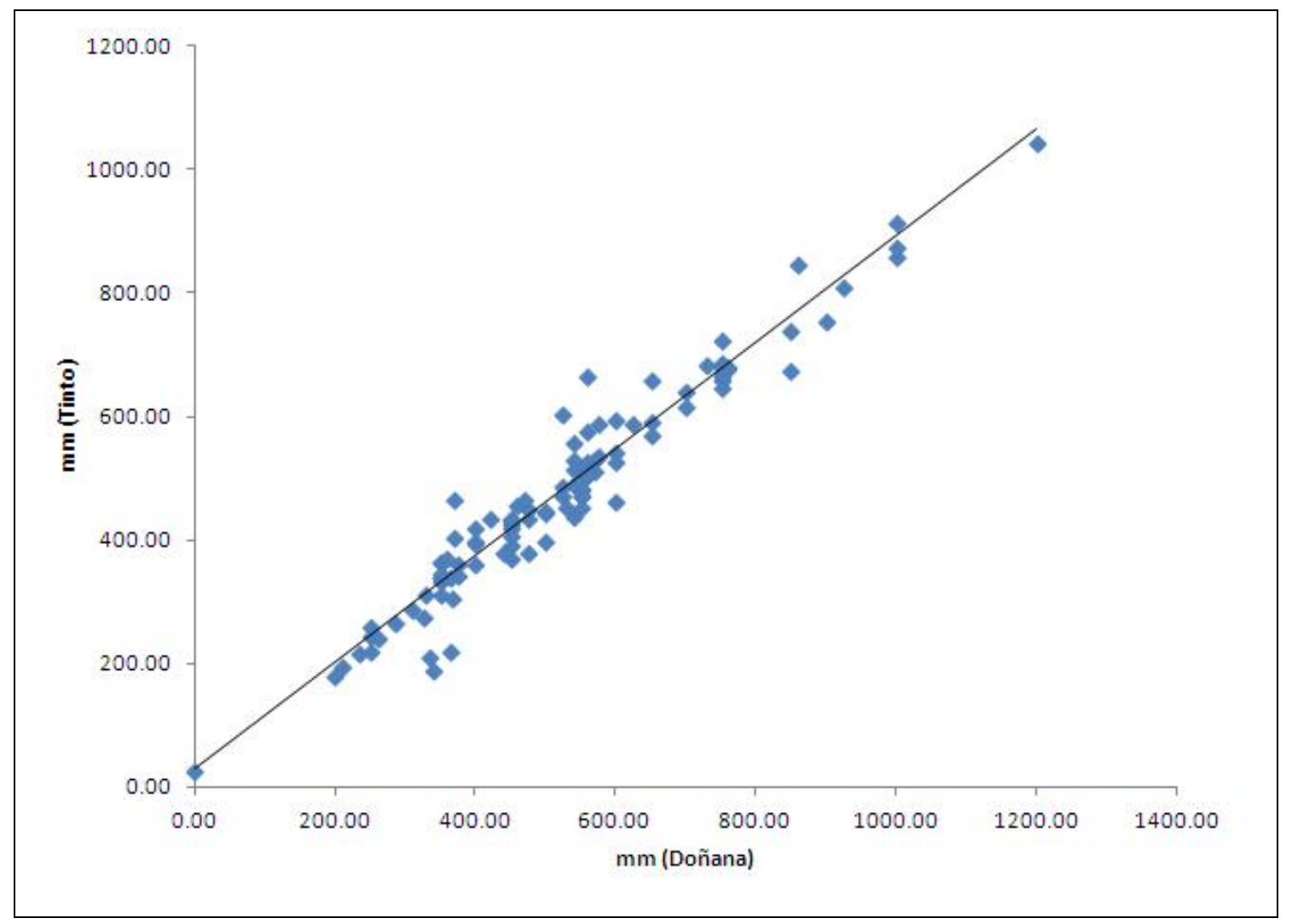

Figure 6: Adjusted Regression Curve for Rainfall Data in Tinto Salt-Marshes

The equation is: 


$$
\begin{aligned}
& y=354.936+0.857 \times P-0.165 \times A \\
& r=0.97 \\
& R^{2}=0.94
\end{aligned}
$$

Where " $\mathrm{y}$ " is the prediction of rainfall in the Tinto salt-marshes in $\mathrm{mm}$, " $\mathrm{P}$ " is the rainfall data in Doñana salt-marshes in $\mathrm{mm}$ and " $\mathrm{A}$ " is the year.

According to [7], and after analyzing photogrammetric images, a progressive decrease in annual water surface was obtained in Tinto salt-marshes, to be main causes, on one hand the increase of human activity around of study area, and moreover the cumulative decrease of rainfall, which indicates (Figure 5) that the environment of Tinto is under the influence of a dry period.

The Tinto salt-marshes area analysis showed that the 1960s had the most water surface that the 1990s and 2000s, with no significant differences between 1990s and 2000s.

The $32,867,946.31 \mathrm{~m}^{2}$ of Tinto salt-marshes, corresponding to the maximum area flooded, are equivalent to a maximum volume of $48.35 \cdot 10^{6} \mathrm{~m}^{3}$ after performing the prediction.

After extrapolating data from photogrammetric images to Ilwis GIS, was carried out a joint analysis using different DEM to estimate the depth of the study area. Likewise, and for each period and UAV data, according to [5], significant relationships were observed (Table 1) between the volume of water and the Tinto salt-marshes surface, not becoming part of the model the estimated depth perhaps due to the peculiarities of the Tinto river and its importance for the study of life in extreme conditions, resulting in that the anthropic factor may be low enough so as to influence its variation along with tides. Table 1 also shows estimated volume and area equation in Tinto salt-marshes for each period.

\begin{tabular}{|c|c|c|c|}
\hline Period & DEM used & Equation & Significance \\
\hline 1973-1985 & $25 \mathrm{~m}$ & $\begin{array}{l}y=-8.615+1.633 \times S \\
r=0.98 \\
R^{2}=0.91\end{array}$ & $\leq 0.001$ \\
\hline $1985-2010$ & $10 \mathrm{~m}$ & $\begin{array}{l}y=-8.227+1.613 \times S \\
r=0.98 \\
R^{2}=0.91\end{array}$ & $\leq 0.001$ \\
\hline UAV data & $5 \mathrm{~m}$ & $\begin{array}{l}y=-8.627+1.635 \times S \\
r=0.98 \\
R^{2}=0.92\end{array}$ & $\leq 0.001$ \\
\hline
\end{tabular}

Table 1: Prediction of volume in each period according to the DEM used (" $y$ " is the prediction of volume in the Tinto salt-marshes in $\mathrm{hm}^{3}$ and " $\mathrm{S}$ " is the estimated surface in these salt-marshes in $\mathrm{km}^{2}$ )

The estimated depth (Table 2 ) was obtained through iterative processes using a total of five hundred random sample points selected in the photogrammetric images, a necessity to identify the eroded soil in these salt-marshes. 
Table 2: Summary of estimated depth in each control point and in each DEM used

\begin{tabular}{|c|c|c|c|c|c|c|c|}
\hline \multirow[t]{2}{*}{$\begin{array}{l}\text { Control } \\
\text { point no }\end{array}$} & \multicolumn{3}{|c|}{$\begin{array}{c}\text { Estimated depth }(\mathrm{m}) \text { in } \\
\text { each DEM used }\end{array}$} & \multirow[t]{2}{*}{$\begin{array}{l}\text { Control } \\
\text { point } n=\end{array}$} & \multicolumn{3}{|c|}{$\begin{array}{c}\text { Estimated depth }(m) \text { in } \\
\text { each DEM used }\end{array}$} \\
\hline & $25 \mathrm{~m}$ & $10 \mathrm{~m}$ & $5 \mathrm{~m}$ & & $25 \mathrm{~m}$ & $10 \mathrm{~m}$ & $5 \mathrm{~m}$ \\
\hline 1 & 0.16 & 0.16 & 0.16 & 13 & 3.08 & 3.05 & 3.07 \\
\hline 2 & 0.32 & 0.24 & 0.30 & 14 & 3.08 & 3.08 & 3.10 \\
\hline 3 & 0.33 & 0.33 & 0.38 & 15 & 3.10 & 3.09 & 3.10 \\
\hline 4 & 1.20 & 0.77 & 1.07 & 16 & 3.10 & 3.10 & 3.11 \\
\hline 5 & 1.50 & 1.35 & 1.68 & 17 & 3.11 & 3.11 & 3.11 \\
\hline 6 & 1.70 & 1.60 & 1.73 & 18 & 3.19 & 3.15 & 3.18 \\
\hline 7 & 2.00 & 1.85 & 1.98 & 19 & 3.21 & 3.20 & 3.23 \\
\hline 8 & 2.45 & 2.23 & 2.42 & 20 & 3.22 & 3.22 & 3.22 \\
\hline 9 & 2.78 & 2.62 & 2.81 & 21 & 3.23 & 3.23 & 3.23 \\
\hline 10 & 2.95 & 2.87 & 3.00 & 22 & 3.24 & 3.24 & 3.24 \\
\hline 11 & 3.00 & 2.98 & 3.04 & 23 & 3.31 & 3.28 & 3.30 \\
\hline 12 & 3.02 & 3.01 & 3.03 & - & - & - & - \\
\hline
\end{tabular}

Also, one-way analysis of variance for correlated samples [13] was carried out for the estimate depth in each period, whose result is shown in Table 3.

Table 3: ANOVA summary for estimated depth

\begin{tabular}{|l||l|c|c|c|c||}
\hline & \multicolumn{1}{|c|}{ SS } & df & MS & F & P \\
\hline \hline $\begin{array}{l}\text { Treatment } \\
\text { (between groups) }\end{array}$ & 0.0775 & 2 & 0.0387 & 10.47 & 0.000191 \\
\hline Error & 0.1647 & 44 & 0.0037 & - & - \\
\hline Blocks (periods) & 74.4531 & 22 & - & - & - \\
\hline Total & 74.6953 & 68 & - & - & - \\
\hline
\end{tabular}

Likewise, and in order to check the differences between periods, a Tukey HSD test was completed, where was observed a significant difference $(p \leq 0.01)$ between period 1 (1973-1985) and 2 (1985-2010), and between period 2 and 3 (UAV data), an expectable result as a consequence of the different DEMs used. However, the interaction between period 1 and 3 is non-significant, probably because the UAV was so high (50 $\mathrm{m}$ above ground) that it was able to capture the density of marsh vegetation in full, resulting a random resemblance to the model obtained in the first period. This in turn is related to the middle of the second period, with establishment in the area of the figure of natural landscape, giving rise to strong ecological 
preservation for the purpose of maintaining the marsh, reason that in 2013 the model is very similar to the first period (in this period the low density of buildings and population in areas close to Tinto salt-marshes gave rise to its almost complete ecological maintenance).

\subsection{Prediction of the Erosion in Tinto Salt-Marshes}

Sediment transport was obtained between consecutive periods through pixel evaluation in Tinto salt-marshes by contrast of the different DEMs used (Figure 7). In this Figure 7 is simulated the sediment transport for the total of study period starting from the characteristics (rainfall and temperature) of each period.

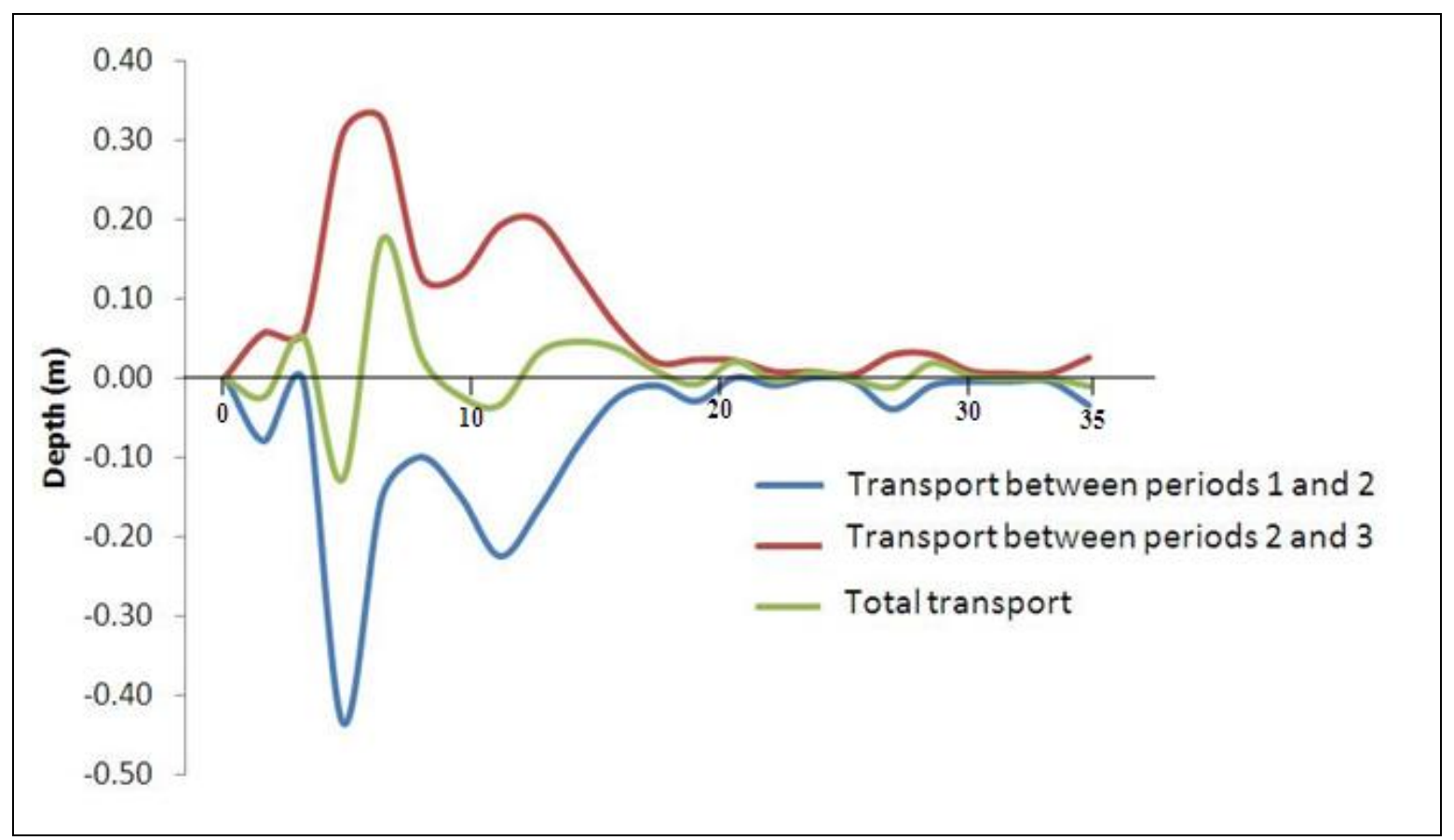

Figure 7: Depth Variations in Tinto Salt-Marshes by Sediment Transport During the Study Period (35 years)

After, a multiple linear regression was applied to all data obtained to be able to predict the total volume of eroded soil (Equation 5 ) in the study period. Further, the original images were classified using [14] (Figures 8 and 9).

$$
\begin{aligned}
& y=0.008-0.563 \times S D+2.903 \times T \\
& r=0.937 \\
& R^{2}=0.867
\end{aligned}
$$

Where " $\mathrm{y}$ " is the prediction of total volume of eroded soil in the Tinto salt-marshes in $\mathrm{hm}^{3}$, "SD" is the equivalent area, in $\mathrm{km}^{2}$, in which has occurred the volume of eroded soil, and which has caused an increase or decrease in the level " $\mathrm{T}$ " of the bed of Tinto salt-marshes in $\mathrm{m}$. 


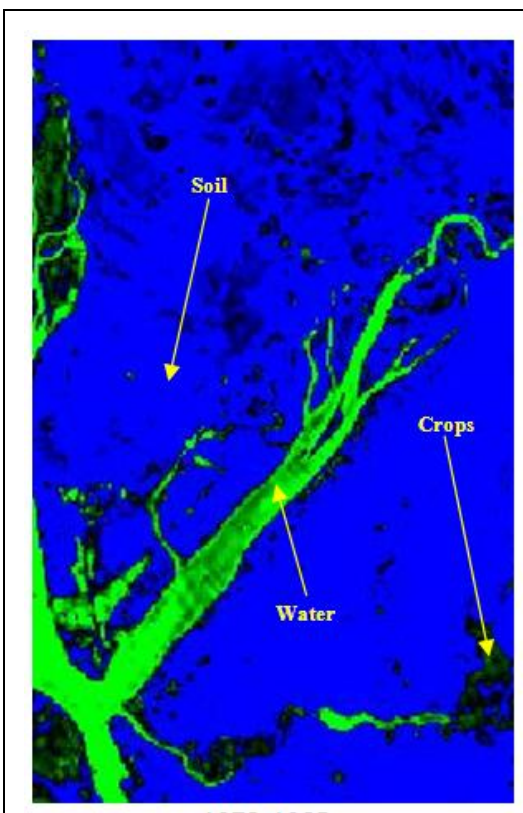

1973-1985

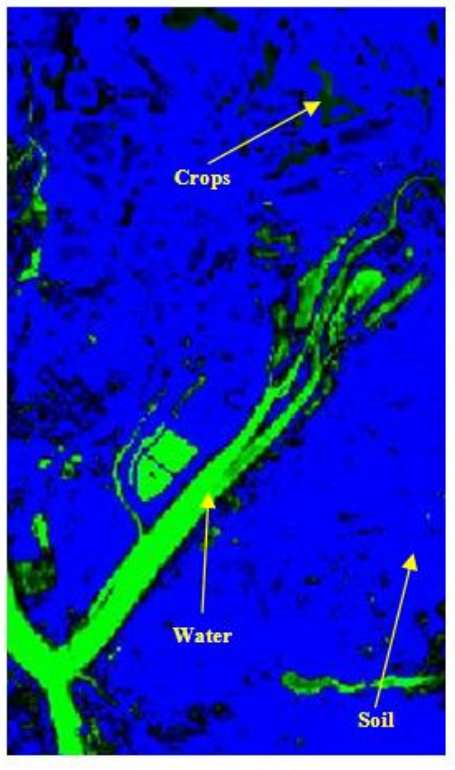

$1985-2010$

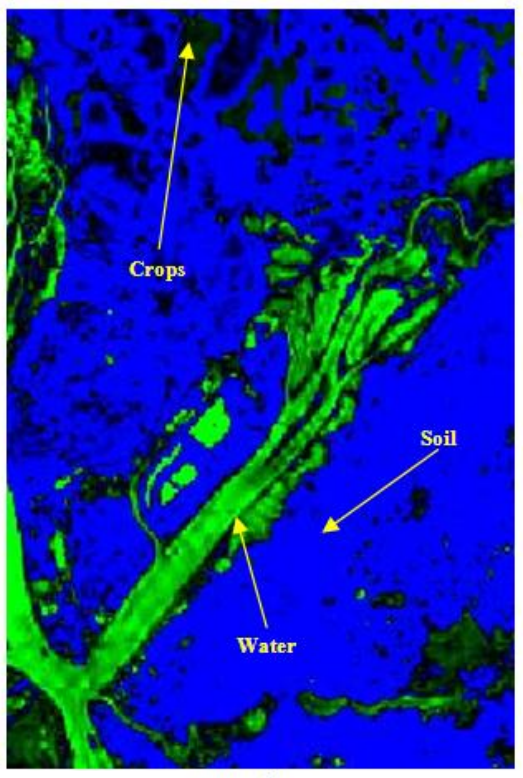

UAV data

Figure 8: Image Classification During the Study Period

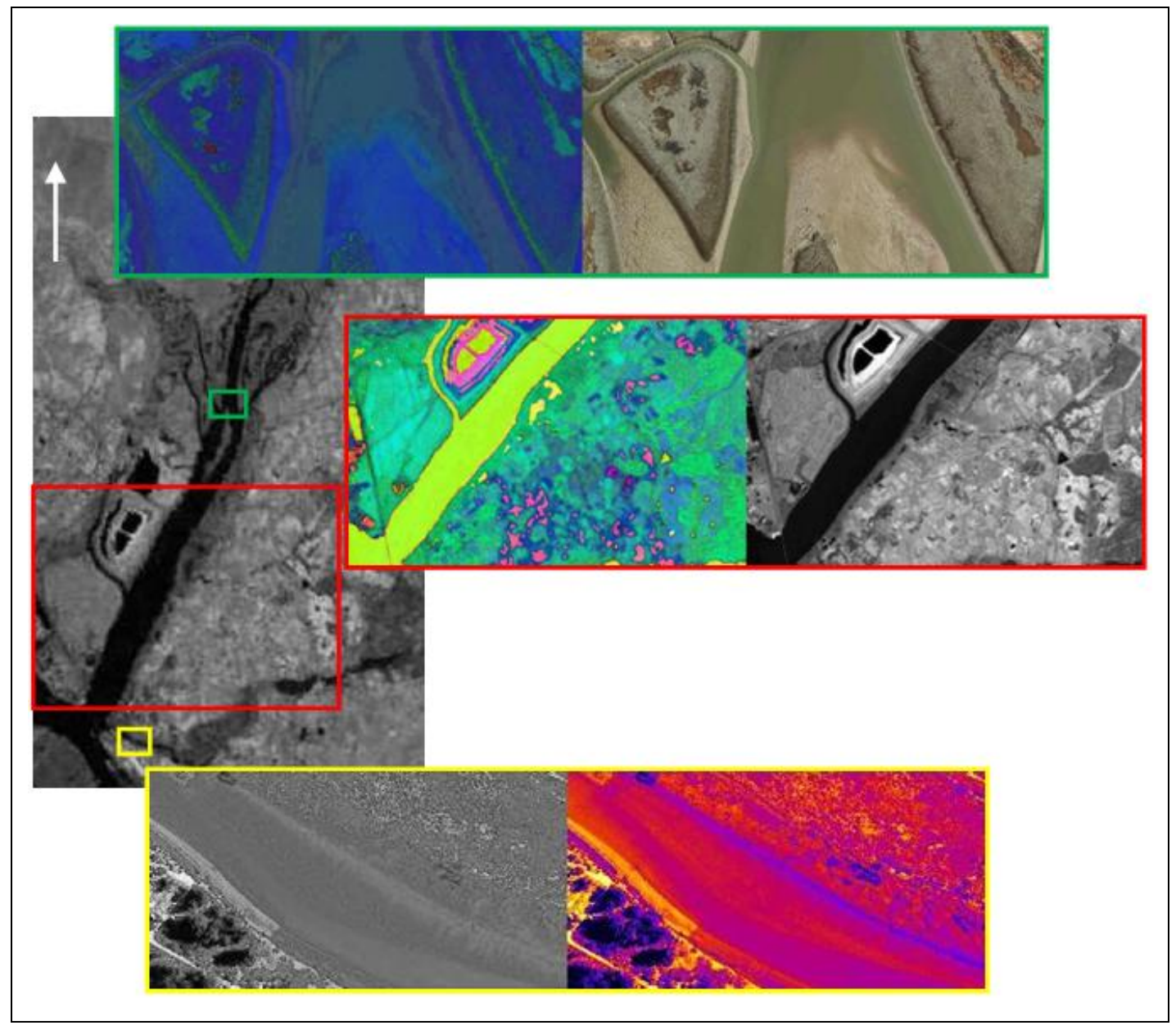

Figure 9: Image Classification in the Study Area 
Erosion dynamic divides Tinto salt-marshes into two zones. The Southern zone presents the highest erosion rates due to tidal effects to a greater extent, with a mean value of total erosion of $0.19 \mathrm{~m}$. Also, the higher levels of anthropogenic pressures (industrial activities among others) might contribute to increase the erosion [15]. However, in the Northern area, with a mean value of total erosion of $0.11 \mathrm{~m}$, and with the existence of the Tartessos' Industrial Park, the dumping of raw sewage and solid waste increase the vulnerability of the area which can mask the real value of total erosion.

The erosion in the Tinto salt-marshes has caused, in the total of study period, a loss of $3,850,000 \mathrm{~m}^{2}$ of equivalent area giving rise to a total volume of eroded soil of $-1,136,640 \mathrm{~m}^{3}$. According to [15], this erosion hinders the development of marshes by successional processes.

\section{Conclusion}

In the Tinto salt-marshes, Southwest of the Iberian Peninsula, the different causes that give rise to the erosion processes were investigated. The results, after analyzing the meteorological data, showed an annual filling process coinciding with the months of highest rainfall, and a water loss concentrated in the summer months. In this regard, the use of different DEMs gave rise to the prediction of volumes with significant differences between periods. One of the main factors of these significant differences is the ecological preservation of the study area in the middle of the second period (1985-2010). This is related to the gradual increase in temperature in recent years, and with the gradual decrease of rainfall (dry period), which together with the slow accumulation of sediments favors the loss of equivalent area in the total of the study period.

In turn, the LUC produced in Tinto salt-marshes is related to loss of wetlands and littoral water areas, not only because of the two processes that accelerate the conversion of forest stand in scrub areas or pastureland and therefore the change of typology within the LUC of forestry and natural areas, but also to the progressive increase of the negative rate of eroded soil (sediment deposition) that might also reflect lower energy, and therefore a possible rise in sea level, resulting in a decrease in the kinetic energy in the Tinto river [16].

Similar results were found in the prediction of the erosion processes using both photogrammetric and UAV images, so it necessary to emphasize the importance of using UAV's to study phenomena related to the environment, and its suitability in the study and evolution of LUC.

\section{REFERENCES}

[1]. Ian P. Prosser, Ian D. Rutherfurd, Jon M. Olley, William J. Young, Peter J. Wallbrink, and Chris J. Moran, LargeScale Patterns of Erosion and Sediment Transport in River Networks, with Examples from Australia. Mar. Freshwater Res., 2001. 52: p. 81-99.

[2]. Ramírez-Juidías, E., López-Lineros, M., and Madueño-Luna, A., Predicción anual de los cambios volumétricos de las Marismas de Doñana mediante el uso de imágenes satélite, in Book Abstracts $V$ Congreso Nacional y Il Congreso Ibérico Agroingeniería, Sociedad Española de Agroingeniería, Editor 2009. p. 199-200. 
Emilio Ramírez-Juidías; Study of Erosion Processes in the Tinto Salt-Marshes with Remote Sensing Images, Advances in I mage and Video Processing, Volume 2 No 4, Aug (2014); pp: 39-52

[3]. Custodio, E., Aguas subterráneas y humedales, in Proceeding Book VII Simposio de Hidrología, Asociación Española de Hidrólogos, Editor 2001. p. 3-30.

[4]. Joachim Hill, and Brigitta Schütt, Mapping Complex Patterns of Erosion and Stability in Dry Mediterranean Ecosystems. Remote Sens. Environ., 2000. 74: p. 557-569.

[5]. Ramírez-Juidías, E., Tejero-Manzanares, J., Moreno-Fresno, J.J., Justicia Segovia, M., Madueño Luna, A., and López-Lineros, M., Land Use Changes and Volumetric processes in the Tinto Salt-Marshes, in Book Abstracts 3rd International Conference on Challenges in Environmental Science and Computer Engineering, G. Lee, Editor 2014. p. 5-5.

[6]. Ojeda-Zújar, J., and Márquez-Pérez, J., Modelos Digitales de Elevaciones (MDE) para la Caracterización Altimétrica de Espacios Marismeños: Las Marismas del Odiel (Huelva). Rev. Soc. Geol. España, 1997. 10(1-2): p. 147-161.

[7]. Juidias, E.R., Segovia, M.J., and Luna, A.M., New Method to Predict the Volumetric Changes in the Odiel Marshes (Huelva, Spain). Lecture Notes in Engineering and Computer Science: Proceding of the Word Congress on Engineering, 2013, U.K., 3-5 July, 2013, London. p. 1335-1339.

[8]. Castellanos, E.M., Nieva, F.J., Luque, C.J., and Figueroa, M.E., Modelo Anual de la Dinámica Sedimentaria en una Marisma Mareal Mediterránea. Cuaternario y Geomorfología, 1998. 12(3-4): p. 69-76.

[9]. Henry, J.B., Matgen, P., Tholey, N., Pfister, L., Hoffmann, L., and De Fraipont, P., Vers une Intégration des Techniques Spatiales pour la Gestion des Inondations. Bulletin de la Société Française de Photogrammétrie et de Télédétection, 2003. 172: p. 99-106.

[10]. Matgen, P., Schumann, G., Henry, J.B., Hoffmann, L., and Pfister, L., Integration of SAR-Derivated River Inundations Areas, High-Precision Topographic Data and a River Flow Model Toward Near Real-Time Flood Management. International Journal of Applied Earth Observation and Geoinformation, 2007. 9: p. $247-263$.

[11]. Instituto de Estadística de Andalucía, Entorno físico en Andalucía: estadísticas históricas del siglo XX. 1st edition ed2007, Sevilla:Junta de Andalucía (Spain). 306.

[12]. Consejería de Medio Ambiente, Medio siglo de cambios en la evolución de usos del suelo en Andalucía 19562007. 1st edition ed2011, Sevilla:Junta de Andalucía (Spain). 174.

[13]. Lowry, R. VassarStats: Website for Statistical Computation, http://vassarstats.net/anova1u.html. 2001.

[14]. Ramírez-Juidías, E., Pozo-Morales, L., and Galán-Ortiz, L., Procedimiento para la Obtención de una Imagen Teledetectada a Partir de Fotografía. 14/06/2013. Universidad de Sevilla, Spain, Patent no P201300573 (with extension to International Patent W2014000097).

[15]. Castillo, J.M., Rubio-Casal, A.E., Luque, C.J., Nieva, F.J., and Figueroa, M.E., Wetland Loss by Erosion in Odiel Marshes (SW Spain). Journal of Coastal Research, 2002. 36: p. 134-138.

[16]. Rogers, C.E., and McCarty, J.P., Climate Change and Ecosystems of the Mid-Atlantic Region. Climate Research, 2000. 14(3): p. 235-244. 